\author{
Alfred SZYDEŁKO ${ }^{1}$ \\ Renata BIADACZ ${ }^{2}$
}

\title{
THE ROLE OF FINANCIAL STATEMENT IN PERFORMANCE MANAGEMENT
}

The essence of financial statements has been used as a background to present the elements of performance management, providing the required characteristics of balance, profit and loss account, additional information, cash flow statement, statement of changes in equity and the business activity report as a supplementary statement of the financial statement of selected entities.

The article focuses particularly on the possibilities of using financial statements as a final product of financial accounting, used as a source of data supporting the process of performance management. The paper contains considerations concerning traditional methods of application of financial statement in performance management. It also indicates directions for improvements in the structure and principles of preparing financial statements in order to increase the usefulness of the provided data in performance management. The conducted analysis leads to the conclusion that particular elements of financial statements may be very useful in assessing performance in selected areas of performance management. It particularly concerns the multidimensional measurement of property resources, results of activity, cash flows (financial measures), as well as various assessments and judgements, including the evaluation of effects, determination of risk factors and specification of threats (nonfinancial measures). Legally formalised by the accounting act, Polish financial statements provide limited capabilities of using in performance management. The entities that prepare financial statements according to the International Accounting Standards/International Financial Reporting Standards have considerably better capabilities in that field. The analysis has been prepared using the methods of review and analysis of literature and legal acts, while conclusions have been based on the methods of induction, deduction and analogical reasoning.

Keywords: performance management, financial accounting, financial statement.

\section{INTRODUCTION}

Performance management is all about improvement - synchronizing improvement to create value for and from customers with the result of economic value creation to stockholders and owners ${ }^{3}$. Enterprise performance management requires creating a database in a form of a proper information system. The primary source of information concerning the performance of the company is accounting, which is the most important system of business activity measurement.

\footnotetext{
${ }^{1}$ Alfred Szydełko, PhD, Zakład Finansów, Bankowości i Rachunkowości, Wydział Zarządzania, Politechnika Rzeszowska, 35-959 Rzeszów, Al. Powstańców Warszawy 8, mail: szydelko@ prz.edu.pl

${ }^{2}$ Renata Biadacz, PhD, Instytut Finansów, Bankowości i Rachunkowości, Wydział Zarządzania, Politechnika Częstochowska, 42-200 Częstochowa, ul. Armii Krajowej 19b, mail: rbiadacz@zim.pcz.pl

${ }^{3}$ G. Cokins, Performance Management. Integrating Strategy, Executions, Methodologies, Risk and Analytics, John Wiley\&Sons, Hoboken, New Jersey 2009, p. 9.
} 
In business practice, accounting is identified with the "accounting system", functioning as a permanently integrated registration and information system that should provide a reliable and clear presentation of the property and financial situation as well as the financial result of the company. According to the Polish balance sheet law, one of the key elements of business entity accounting is preparing financial statements, and in particular cases, also analysing and announcing them. ${ }^{4}$

The financial statement is a final element of business entity financial accounting and contains multidimensional data obtained from the accounting books. To a small extent, data from management accounting are also used in preparation of financial statements.

The aim of this study is to indicate the possibilities of using financial statement as a source of economic data supporting performance management.

The assumed goal has been achieved using the methods of induction, deduction and analogical reasoning on the basis of the study of Polish reference books and analysis of legal acts concerning accounting.

\section{THE ESSENCE AND STRUCTURE OF THE FINANCIAL STATEMENT}

Financial reporting uses data obtained from financial accounting records kept by the company. It presents valuable information with any required supplementary descriptions. Financial data included in particular components of the financial statement, due to proper organisation and grouping, should enable a comprehensive assessment of the property and financial situation of the enterprise and the achieved results.

According to the conceptual assumptions for preparing and presentation of financial statements ${ }^{5}$, fundamental quality features of practical financial data are usefulness and reliable presentation, determined by comparability, verifiability, timeliness and comprehensibility (supplementary features). These quality features of the financial statement, confirmed by a revision in larger entities ${ }^{6}$, determine the usefulness of the presented information from the point of view of the recipients.

The major task of the system of financial accounting oriented on performance is to provide data supporting the process of performance management. Financial accounting achieves it directly and indirectly.

Performance management of the enterprise is based on using financial measures (expressed in monetary units) and non-financial measures (not expressed in monetary units).

The system of financial accounting, by its nature supports generating data required to build financial measures. The categories that create critical financial measures, evaluated directly in financial accounting, are:

- property resources,

- results (effects) of activity,

- cash flows.

\footnotetext{
${ }^{4}$ Article 4 par. 3 of the Accounting Act of 29 September 1994 (consolidated text, Journal of Laws of 2013, item 330 , as amended).

${ }^{5}$ Międzynarodowe Standardy Sprawozdawczości Finansowej [International Financial Reporting Standards], Stowarzyszenie Księgowych w Polsce, Warszawa 2011

${ }^{6}$ Z. Fedak, Rewizja rocznych sprawozdań finansowych, part I, Stowarzyszenie Księgowych w Polsce, Warszawa 1996, pp. 8-10
} 
Property resources of the company are presented in form of the account balance as of the particular date in objective (assets) and subjective (liabilities - capitals) aspects, with a special focus on changes in equity (fund).

The result of activity has the form of income, extraordinary profit, extraordinary cost or loss, as well as individual categories of financial result.

Cash flows are presented in the context of inflows and expenses for operating, investment and financial activity.

Beside financial measures, influenced directly and exclusively by the categories determined in financial accounting, there are also non-financial measures in which data from the financial accounting system are used in estimating other measures of financial achievements (e.g. total corporate value or value creation measures).

Best quality financial data used in company performance management (used for creating financial measures and then in measuring achievements), are included in the financial statement. It presents numerical data expressed in monetary units, that synthetically characterise the property and financial condition as well as the results achieved by the given entity.

The financial statement reflects global economic events related with the business activity of the enterprise, that are transformed into numbers and included (processed) in the accounting books constituting the financial statement database. Mastering and understanding the data included in the financial statement provides a comprehensive image of the enterprise (property, finances and results) ${ }^{7}$.

The financial statement may concern a single enterprise or many enterprises. For that reason, unit and consolidated financial statements can be distinguished.

Unit financial statement of a company encompasses the balance sheet, profit and loss account and additional information. In addition to that, larger entities, subject to financial statement analysis, prepare cash flows statements and a statement of changes in equity. Yearly financial statements of joint-stock companies, limited liability companies, partnerships limited by shares, mutual organisations, cooperatives, state-owned enterprises and other entities are provided along with a yearly business activity report (however, it does not constitute a financial statement component but only its supplement).

Financial statement components are mutually related and constitute an internally consistent entirety, thus they should not be treated as separate and not related parts ${ }^{8}$. The structure of the financial statement is presented in figure 1.

\footnotetext{
${ }^{7}$ K. Sawicki, Analiza finansowa na potrzeby rady nadzorczej, „, Rachunkowość”, 2001, nr 3, p. 144.

${ }^{8}$ E. Nowak, Analiza sprawozdań finansowych, PWE, Warszawa 2014, p. 16.
} 
Figure 1. The structure of financial statement

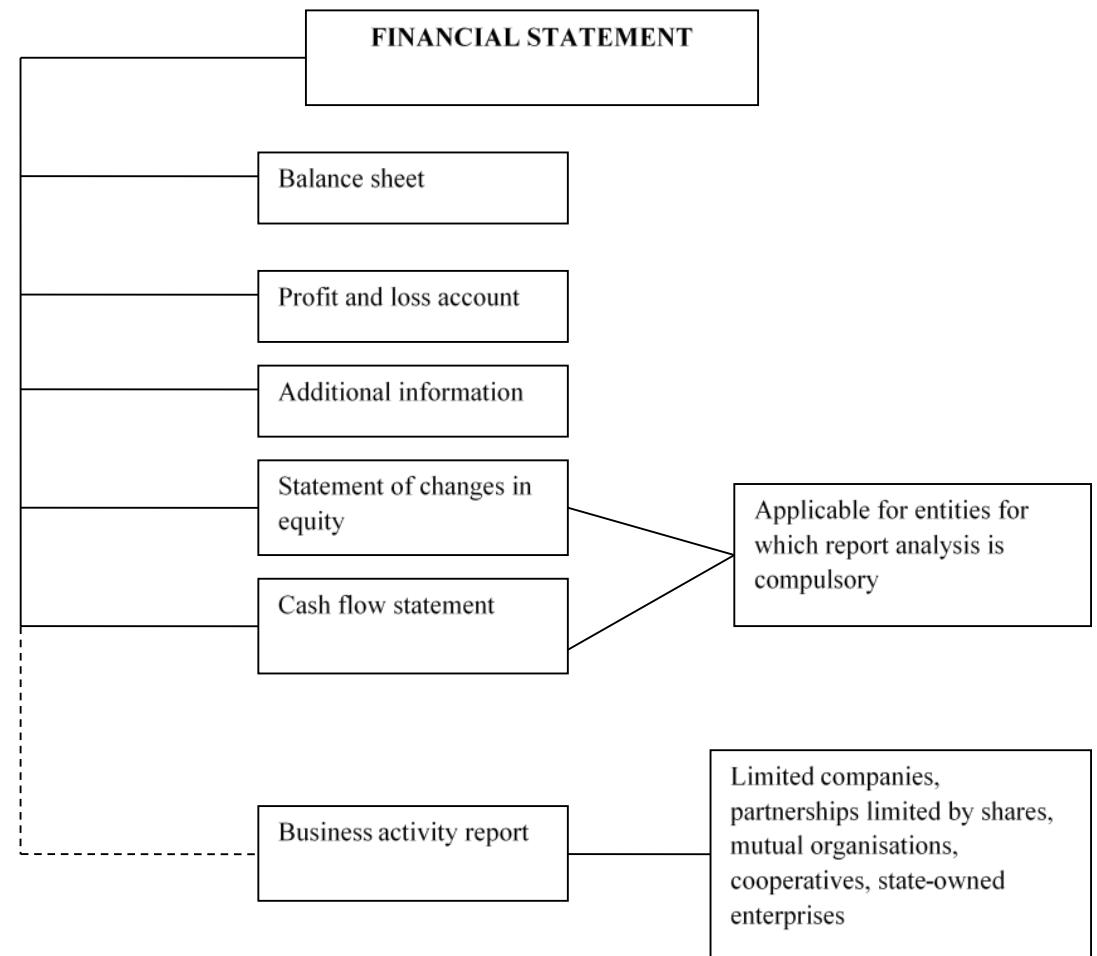

Source: individual study.

Consolidated financial statement concerns corporate groups and is prepared by a parent unit. It contains the data concerning the parent unit and its subsidiaries.

A multi-plant enterprise which distinguishes organisational units functioning within its structure, that prepare financial statements individually, submits a common financial statement which is a sum of all items of the financial statement of the unit and its branches (plants), with exclusions envisaged by the balance sheet law.

The financial statement should present data concerning the current financial year, as well as the previous financial year. It provides the possibility to compare the changes that occurred in time using the values specified in the financial statement.

Balance sheet is a key component of the financial statement that provides information on the property and financial condition of the enterprise. It summarises by value the property resources of the enterprise (assets) as well as the sources of financing (liabilities) at a given moment (balance sheet date). In other words, it is a "photograph" of the enterprise which represents it property and financial status on a given day.

Profit and loss account is one of the major and obligatory components of the unit financial statement. It provides the information concerning the efficiency of individual types of activity and the overall financial result of the enterprise. The profit and loss ac- 
count presents stream values, i.e. the income and profit gained in a given reporting period as well as costs and losses incurred - in that sense it shows the financial result fulfilment during the reporting period.

The profit and loss account includes profit and income as well as costs and losses determined by economic events taking place during the reporting period, and also results of balance sheet valuation of assets and liabilities as of the balance sheet date.

The financial result indicated in the balance sheet has the character of a synthetic information, while in the profit and loss account, it has a more detailed form. The multilevel layout of the profit and loss account allows to distinguish five categories of the financial result ${ }^{9}$ :

1) sales result,

2) operating activity result,

3) business activity result,

4) gross financial result,

5) net financial result.

Cash flow statement is an analytical presentation of the data presented in the balance sheet, concerning the change in funds that has been made in the reporting period. It is prepared on the basis of the balance sheet, the profit and loss account, additional information as well as the data included in the summaries of turnover and general ledger accounts balances and also in summaries of subledgers accounts balances. It provides an answer to the question whether the accounting profit was followed by cash taking and whether possible loss would result in sudden loss of financial liquidity ${ }^{10}$.

This statement indicates incoming and outgoing cash flows that have effect on the condition of funds. The result category of the cash flow statement are net cash flows. They are the difference between cash takings and expenditures that took place during the reporting period. They may have the form of surplus funds or shortage of funds.

Cash flows should be indicated separately for particular areas of activity: operating, investment and financial.

Summary of changes in equity is an analytical presentation of the data concerning the shape of individual parts of equity, presented commonly in balance sheet liabilities. It contains information on increases or decreases in share capital, outstanding share capital contributions, own shares (stocks), capital reserves, revaluation reserve, other reserve capital and accumulated profit (loss) after taxation from previous years - with specified titles of the presented changes.

Additional information is a descriptive and numerical supplement and specification of the data indicated in particular quantitative summaries (reports) included in the yearly financial statement. The supplementation consists in presenting detailed data and explanations to the aggregated values indicated in the balance sheet, profit and loss account, summary of changes in equity and cash flow statement. The specification consists in disclosing information not mentioned in the other parts of the report, both descriptive and numerical, given in monetary and natural units, that may be significant for the assessment of the economic and financial condition of the enterprise.

\footnotetext{
${ }^{9}$ In the profit and loss account of natural persons and partnerships (civil law partnerships, general partnerships, limited liability partnerships, limited partnerships, partnerships limited by shares) net financial result is equal to gross financial result - as PIT income tax is not paid by companies but each owner (partner) individually.

${ }^{10}$ G. K. Świderska, Jak czytać sprawozdanie finansowe- przewodnik menedżera, Difin, Warszawa 2009, p. 118.
} 
Additional information encompasses the introduction to the financial statement as well as additional data and explanations. The introduction to the financial statement contains formal and descriptive information concerning the enterprise and assumed accounting solutions.

Additional data and explanations concern the items of the balance sheet, profit and loss account, summary of changes in equity and cash flow statement, proposed profit division or loss coverage method, basic information concerning the employees and enterprise organisational units as well as other information that may be used in order to comprehend the financial statement.

The legislator has not determined the form that additional information should have, therefore each enterprise should assume an individual shape of this report, considering the legal acts and standards to be followed and the functions to be fulfilled. It may be provided in form of a description or charts, or using both descriptions and charts. In practice, the most common format is based on using descriptions and charts.

Business activity statement contains crucial information concerning the property status and financial situation of the enterprise, including the evaluation of effects and indication of risk factors along with description of threats. According to the accounting act, this statement should particularly contain the data concerning:

1) the events having crucial effect on the business activity, that took place during the financial year and later, until the date of acceptance of the financial statement,

2) the expected direction of development,

3) significant achievements in the area of research and development,

4) the current and expected financial situation,

5) the purchase of own shares (stocks) with further purchase characteristics,

6) the branches (plants) of the enterprise,

7) the risk related with possessed financial instruments as well as assumed goals and methods of financial risk management,

8) following the rules of corporate governance (applies only to specific entities).

The act also requires disclosing data in form of financial and non-financial indexes when it is essential to assess the situation of the enterprise, including the information concerning the natural environment and employment as well as additional explanations to the amounts indicated in the financial statement.

The business activity statement attached to the financial statement has a wider economic approach (wide and multi-aspect range), puts emphasis on the usefulness of data in the decision-making process, takes into account the future perspective, introduces nonfinancial (descriptive) information and accepts subjective judgement of the management. As a result, it constitutes a supplement to the financial statement, increasing its informative capacity ${ }^{11}$.

\footnotetext{
${ }^{11}$ E. Nowak, Sprawozdanie z działalności jako źródlo informacji o dokonaniach przedsiębiorstwa, in: Pomiar i raportowanie dokonań przedsiębiorstwa, edited by. E. Nowak, CeDeWu, Warszawa 2012, p. 143.
} 


\section{TRADITIONAL OPTIONS OF USING FINANCIAL STATEMENTS IN PER- FORMANCE MANAGEMENT}

Financial statements may be used in enterprise performance management in various areas and on different levels of management. The typical options of using financial statements drawn up according to the Polish balance sheet law include ${ }^{12}$ :

- using unit and consolidated financial statements in performance management of a corporate group,

- using financial statements of self-balancing plants (branches) in evaluating them as units responsible for result,

- using financial statements in economic and financial analysis on the budget level (planning of achievements), during the implementation (monitoring of achievements) and after completion (evaluation of achievements),

- using the profit and loss account as well as its simplifications in measuring results in responsible units,

- using the cash flow statement in evaluating the fulfilment of assumed relations between cash flows from the operating, investment and financial activity,

- using the balance sheet in creating the optimum structure of the financing sources.

The data included in the financial statement for management purposes, beside the amounts from the current and the previous period, should also include the budgetary information.

There are specific formats of financial statements defined by the Polish balance sheet law, with presentation of categories also indicated by the law. In order to increase their usefulness in measuring achievements, the acceptable alternative options allow to adjust the accounting policy, in particular in the area of the methods of valuation of assets and liabilities as well as determining the financial result, and also the method of running the accounting books.

Other possibilities in this area are provided by the systems of financial accounting based on the rules set by the International Accounting Standards and the International Financial Reporting Standards. These standards do not impose the scope of information to be presented in any financial statement. Financial accounting functioning according to these rules, in order to increase the usefulness of presented information, even promotes presenting new items in financial statements, which allows to adjust them more easily to the management needs.

\section{TRENDS OF IMPROVEMENT OF FINANCIAL STATEMENTS FOR THE PURPOSES OF PERFORMANCE MANAGEMENT}

Measurement of achievements is followed by many challenges for accounting, constituting the informational basis of performance management. It mainly concerns management accounting, but also, to a smaller extent, financial accounting including financial statements.

Performance management requires using many various measures that enable multidimensional measurement and evaluation of achievements in all fields of business activity. The essential condition of using accounting in the role of a system that provides informa-

\footnotetext{
${ }^{12}$ A. Szydełko, Rachunkowość jako baza informacyjna controllingu, in: Controlling dla menedżerów, edited by E. Nowak, CeDeWu, Warszawa 2013, p. 129.
} 
tive support to the processes of performance management, is to create an integrated accounting system, focused on generating multidimensional information concerning various achievements.

The issue of financial statements is associated with the integration of the financial accounting principles, as well as with the integration of financial accounting and management accounting.

The integration processes in financial accounting, oriented on the measurement of achievements, occur less frequently, since their consequences have effect not only on the performance management requirements, but also result in appearance of categories that must meet the requirements of the balance sheet law. It is usually related with improvement of quality of categories already determined in the financial accounting system, rather than generation of new categories allowing to create directly or indirectly new measures of achievements (which would require certain changes in the balance sheet law), which finally improves the informative values of financial statements and also usefulness of achievement measures.

The major area of financial accounting where these processes occur, is the cost account. Appearance of the category of product generation, comprising variable costs and fixed costs in relation with the degree of using the current production capacity of the enterprise, is an example of a hybrid solution ${ }^{13}$ formed as a result of "crossing" the reporting full cost account with the variable cost account ${ }^{14}$. Such integration results in improvement of credibility of data concerning the costs incurred for the products and the costs of the period, and as a consequence, the financial result is determined more precisely as a measure of total yearly business performance of the enterprise. It is specially reflected in the profit and loss account.

The issue of integration of financial accounting and the methods of management accounting in order to improve the possibilities of informative support of performance management, is also interesting. Processes of this type particularly appear in international accounting regulations (standards), e.g. IAS/IFRS, US GAAP) and in the guidelines of the international accounting organisations (e.g. IFAC), and also in the scientific research.

This area of integration particularly concerns the structure of the financial statement. An interesting solution in this field has been presented by J. Gierusz ${ }^{15}$, who proposed measuring economic value added (EVA) using the balance sheet formulas of the profit and loss account.

Irrespective of the integrating processes taking place for the purposes of performance management, there is a noticeable trend of using achievement measurement tools in order to improve the quality and increase the scope of data provided in statements regulated by the balance sheet law. One of the examples is the National Accounting Standard No. 9 "Business activity report" 16 which aims at facilitating the preparation of the financial

\footnotetext{
${ }^{13}$ A. Szydełko, Hybrydowe rachunki kosztów w kreowaniu informacji na potrzeby zarządzania kosztami, „Prace Naukowe Uniwersytetu Ekonomicznego we Wrocławiu, 2010, nr 123, pp. 506-509.

${ }^{14}$ A. Szydełko, Możliwości wkomponowania rachunku kosztów zmiennych $w$ ewidencyjne rozwiązania systematycznego rachunku kosztów, „Controlling i Rachunkowość Zarządcza”, 2000, No. 8.

${ }^{15}$ J. Gierusz, Koszty i przychody w świetle nadrzędnych zasad rachunkowości. Pojęcia. Klasyfikacja. Zakres ujawnień, ODDK, Gdańsk 2005, pp. 232-245.

${ }^{16}$ Announcement No. 4 of the Minister of Finance dated 30 April 2014 concerning the publication of the National Accounting Standard No. 9 "Business activity report", Official Journal of the Minister of Finance of 2014, item 17.
} 
statement as well as other similar statements, according to the needs of the stakeholders, and also promoting good practices in this scope.

That standard requires that in order to characterise the activity, results and situation of the enterprise, the key financial and non-financial measures used for the evaluation should be presented along with a description and indication of the purpose of using, principles of calculation, sources of data, trends and reference to standard values. The recommendations of the standard refer to using the measures originating in the financial statement. In case of measures generated through modification of that statement (EBIT, EVA), any introduced modifications shall be explained.

\section{CONCLUSION}

Environment analysis is particularly important in this context. Effective performance management requires using a range of various data. One of the sources of these data are financial statements, which are the final "product" of financial accounting. They provide credible information required for performance management through the aspect of assessment of the property and financial status of the enterprise, as well as the results achieved.

Supporting performance management with the data provided by financial statements may be fulfilled traditionally, using the existing obligatory formats of these statements, based on the principles of financial statements preparation. The article also indicates the directions for improvements in the structure and principles of preparation of financial statements in order to increase the usefulness of the provided data in performance management.

The conducted analysis has led to the conclusion that particular elements of financial statement are very useful in assessing achievements in selected areas of performance management. It particularly concerns the multidimensional measurement of property resources, results of activity, cash flows (financial measures), as well as various assessments and judgements, including the evaluation of effects, determination of risk factors and specification of threats (non-financial measures). However, Polish financial statements legally formalised by the accounting act provide limited capabilities of using them in performance management. The entities that prepare financial statements according to the International Accounting Standards/International Financial Reporting Standards have considerably better capabilities in that field.

\section{LITERATURE}

[1] Announcement No. 4 of the Minister of Finance dated 30 April 2014 concerning the publication of the National Accounting Standard No. 9 "Business activity report", Official Journal of the Minister of Finance of 2014, item 17.

[2] Cokins G., 2009, Performance Management. Integrating Strategy, Executions, Methodologies, Risk and Analytics, John Wiley\&Sons, Hoboken, New Jersey.

[3] Fedak Z., 1996, Rewizja rocznych sprawozdań finansowych, part I, Stowarzyszenie Księgowych w Polsce, Warszawa.

[4] Gierusz J., 2005, Koszty i przychody w świetle nadrzędnych zasad rachunkowości. Pojęcia. Klasyfikacja. Zakres ujawnień, ODDK, Gdańsk.

[5] Międzynarodowe Standardy Sprawozdawczości Finansowej, 2011, Stowarzyszenie Księgowych w Polsce, Warszawa.

[6] Nowak E., 2014, Analiza sprawozdań finansowych, PWE, Warszawa.

[7] Nowak E., 2012, Sprawozdanie z działalności jako źródto informacji o dokonaniach przedsiębiorstwa, in: Pomiar i raportowanie dokonań przedsiębiorstwa, edited by E. Nowak, CeDe$\mathrm{Wu}$, Warszawa. 
[8] Sawicki K., 2001, Analiza finansowa na potrzeby rady nadzorczej, ,, Rachunkowość”, No. 3.

[9] Szydełko A., 2010, Hybrydowe rachunki kosztów w kreowaniu informacji na potrzeby zarzadzania kosztami, ,Prace Naukowe Uniwersytetu Ekonomicznego we Wrocławiu, No. 123.

[10] Szydełko A., 2000, Możliwości wkomponowania rachunku kosztów zmiennych $w$ ewidencyjne rozwiązania systematycznego rachunku kosztów, „Controlling i Rachunkowość Zarządcza”, No. 8.

[11] Szydełko A., 2013, Rachunkowość jako baza informacyjna controllingu, in: Controlling dla menedżerów, edited by E. Nowak, CeDeWu, Warszawa.

[12] Świderska G.K., 2009, Jak czytać sprawozdanie finansowe- przewodnik menedżera, Difin, Warszawa.

[13] The Accounting Act of 29 September 1994, with further amendments (consolidated text, Journal of Laws of 2013, item 330

\section{ROLA SPRAWOZDANIA FINANNSOWEGO W ZARZĄDZANIU DOKONANIAMI}

Celem opracowania jest wskazanie możliwości wykorzystania sprawozdania finansowego jako źródła informacji ekonomicznych wspomagających zarządzanie dokonaniami. $\mathrm{Na}$ tle istoty sprawozdania finansowego zaprezentowano poszczególne jego elementy, dokonując równocześnie niezbędnych charakterystyk bilansu, rachunku zysków i strat, informacji dodatkowej, rachunku przepływów pieniężnych, zestawienia zmian w kapitałach (funduszach) własnych oraz sprawozdania z działalności jako sprawozdania uzupełniającego sprawozdanie finansowe w wybranych jednostkach. W artykule zwrócono szczególną uwagę na możliwości wykorzystania sprawozdań finansowych jako finalnego produktu rachunkowości finansowej do informacyjnego wspomagania procesów zarządzania dokonaniami. Przeprowadzono rozważania na temat klasycznych możliwości aplikacyjnych sprawozdania finansowego z zarządzaniu dokonaniami. Wskazano równocześnie kierunki doskonalenia konstrukcji i zasad sporządzania sprawozdań finansowych na potrzeby zwiększenia przydatności dostarczanych przez nie informacji na potrzeby zarzadzania dokonaniami. Przeprowadzone rozważania doprowadziły do stwierdzeń, że poszczególne elementy sprawozdania finansowego znakomicie nadają się do pomiaru dokonań w wybranych obszarach zarządzania dokonaniami. Dotyczy to szczególnie wieloprzekrojowego pomiaru zasobów majątkowych, rezultatów działalności, przepływów pieniężnych (mierniki finansowe), jak również różnego rodzaju ocen i osądów, w tym ocenę uzyskanych efektów, wskazanie czynników ryzyka i opis zagrożeń (mierniki niefinansowe). Sformalizowane prawnie przez ustawę o rachunkowości polskie sprawozdania finansowe mają jednak ograniczone możliwości co do ich dostosowywania do potrzeb zarzadzania dokonaniami. Znacznie większe możliwości $\mathrm{w}$ tym zakresie mają jednostki sporządzające sprawozdania finansowe zgodnie $\mathrm{z}$ wymogami MSR/MSSF. W rozważaniach wykorzystano metody przeglądu i analizy literatury oraz aktów prawnych, a wnioskowanie przeprowadzono z uwzględnieniem metod indukcji i dedukcji oraz rozumowania przez analogię.

Słowa kluczowe: zarządzanie dokonaniami, rachunkowość finansowa, sprawozdanie finansowe.

\section{DOI: 10.7862/rz.2016.mmr.55}

Tekst złożono w redakcji: grudzień 2016

Przyjęto do druku: grudzień 2016 